\title{
Perspectives of digestive pest control with proteinase inhibitors that mainly affect the trypsin-like activity of Anticarsia gemmatalis Hübner (Lepidoptera: Noctuidae)
}

\author{
M.E. Pereira' ${ }^{1,2}$, F.A. Dörr ${ }^{1}$, \\ N.C. Peixoto ${ }^{1,2}$, \\ J.F. Lima-Garcia ${ }^{1}$, F. Dörr \\ and G.G. Brito ${ }^{3}$
}

\author{
1Programa de Pós-Graduação em Bioquímica Toxicológica, \\ 2Departamento de Química, Centro de Ciências Naturais e Exatas, \\ ${ }^{3}$ Programa de Pós-Graduação em Agronomia, CCR, \\ Universidade Federal de Santa Maria, Santa Maria, RS, Brasil
}

\section{Correspondence \\ M.E. Pereira \\ Departamento de Química, CCNE Universidade Federal de Santa Maria 97105-900 Santa Maria, RS Brasil \\ Fax: +55-55-3220-8799 \\ E-mail: pereirame@yahoo.com.br \\ Presented at the XVIII Annual Meeting of the Federação de Sociedades de Biologia Experimental, Curitiba, PR, Brazil, August 27-30, 2003. \\ Part of a Master's thesis presented by F.A. Dörr to the Post-graduation Program in Toxicologic Biochemistry, Universidade Federal de Santa Maria, RS, Brazil. \\ F.A. Dörr and J.F. Lima-Garcia were recipients of CAPES fellowships.}

Received April 6, 2005 Accepted August 30, 2005

\section{Abstract}

The present study describes the main characteristics of the proteolytic activities of the velvetbean caterpillar, Anticarsia gemmatalis Hübner, and their sensitivity to proteinase inhibitors and activators. Midguts of last instar larvae reared on an artificial diet were homogenized in 0.15 $\mathrm{M} \mathrm{NaCl}$ and centrifuged at $14,000 \mathrm{~g}$ for $10 \mathrm{~min}$ at $4^{\circ} \mathrm{C}$ and the supernatants were used in enzymatic assays at $30^{\circ} \mathrm{C}, \mathrm{pH} 10.0$. Basal total proteolytic activity (azocasein hydrolysis) was $1.14 \pm 0.15$ absorbance variation $\min ^{-1} \mathrm{mg}$ protein ${ }^{-1}$, at $420 \mathrm{~nm}$; basal trypsin-like activity (N-benzoyl-L-arginine-p-nitroanilide, BApNA, hydrolysis) was $0.217 \pm 0.02 \mathrm{mmol}$ p-nitroaniline $\mathrm{min}^{-1} \mathrm{mg}$ protein ${ }^{-1}$. The maximum proteolytic activities were observed at $\mathrm{pH} 10.5$ using azocasein and at $\mathrm{pH} 10.0$ using BApNA, this $\mathrm{pH}$ being identical to the midgut $\mathrm{pH}$ of 10.0. The maximum trypsin-like activity occurred at $50^{\circ} \mathrm{C}$, a temperature that reduces enzyme stability to 80 and $60 \%$ of the original, when pre-incubated for 5 and $30 \mathrm{~min}$, respectively. Phenylmethylsulfonyl fluoride inhibited the proteolytic activities with an $\mathrm{IC}_{50}$ of $0.39 \mathrm{mM}$ for azocasein hydrolysis and of $1.35 \mathrm{mM}$ for BApNA hydrolysis. Benzamidine inhibited the hydrolysis with an $\mathrm{IC}_{50}$ of 0.69 and $0.076 \mathrm{mM}$ for azocasein and BApNA, respectively. The absence of cysteine-proteinases is indicated by the fact that 2-mercaptoethanol and L-cysteine did not increase the rate of azocasein hydrolysis. These results demonstrate the presence of serine-proteinases and the predominance of trypsin-like activity in the midgut of Lepidoptera insects, now also detected in A. gemmatalis, and suggest this enzyme as a major target for pest control based on disruption of protein metabolism using proteinase inhibitors.
Key words

- Anticarsia gemmatalis

(Lepidoptera: Noctuidae)

- Azocasein hydrolysis

- BApNA hydrolysis

- Proteinase inhibitors

- Protein digestion

- Serine-proteinases 


\section{Introduction}

As soybean becomes a major world food source, the expansion of its cultivation is likely to increase crop vulnerability to insect pests (1). Among these pests, the velvetbean caterpillar, Anticarsia gemmatalis Hübner (Lepidoptera: Noctuidae), is the most important defoliator (2). The larvae have caused economic losses in the South of the United States and in Latin America (1), with the applications of insecticides being required for their control. In Brazil, the successful implementation of an Integrated Pest Management program to control this insect involving the use of the nucleopolyhedrovirus of A. gemmatalis (3) has led to great economic and environmental savings (4).

The development of crops resistant to insect pests using Bacillus thuringiensis (5) is considered to be an essential component of this Integrated Pest Management program. Genetic engineering enables the transfer of novel genes to economically important plants in order to produce resistant cultures (6). Genes encoding inhibitors that target digestive proteolytic enzymes of herbivore insects are candidates for plant transformation (7). Proteinase inhibitors are found in a variety of plant species, where they are believed to have a role in defense against pests (8). The potential use of these inhibitors as resistance factors has been demonstrated (9-13). The stable binding of these inhibitors to digestive proteinases causes a delay in protein digestion. The induction of protein synthesis and consequently the pernicious hypersecretion of digestive enzymes occurring to compensate for this inhibition lead to the depletion of essential amino acids, and this negative amino acid balance may result in retarded development and eventually in death (14).

Proteinases are divided into four classes based on the amino acid or metal ion involved in the catalytic site which cleaves peptide bonds: serine, cysteine, aspartic, and metalloproteases. All these classes of pro- teases have been demonstrated in insects (15). Except for some hemipteran and coleopteran species, in most insect groups initial protein digestion relies on serine-proteinases, particularly trypsin and chymotrypsin (15). In Lepidoptera larvae, these enzymes have been shown to have a high $\mathrm{pH}$ optimum, which is consistent with the alkaline conditions in their midgut (16).

Digestive enzymes have been selected as targets for pest control methods and their participation in the activation of Bacillus thuringiensis endotoxins, as well as their efficacy against A. gemmatalis have also been demonstrated $(17,18)$. Although there is a vast literature dealing with proteolytic enzymes in Lepidoptera larvae, few reports are available regarding $A$. gemmatalis. Since proteolytic enzymes are responsible for protein digestion and consequently for the supply of amino acids needed for development, knowledge about the activity of these enzymes and their sensitivity to inhibitors is fundamental for future programs of pest control. In the present paper, we report the partial characterization of proteolytic activities in the midgut of A. gemmatalis larvae.

\section{Material and Methods}

\section{Material}

Sulfanilamide-azocasein, N-benzoyl-L-arginine-p-nitroanilide (BApNA), N-benzoylL-tyrosine-p-nitroanilide (BTpNA), phenylmethylsulfonyl fluoride (PMSF), benzamidine (BZD), and iodoacetic acid were purchased from Sigma-Aldrich Co. (St. Louis, MO, USA). Reagen (Rio de Janeiro, RJ, Brazil) supplied ethylenediaminetetraacetic acid (EDTA), Lcysteine, dimethyl sulfoxide and bovine serum albumin fraction V. All other reagents used were of analytical grade.

\section{Insect rearing}

The study was conducted in the Labora- 
tory of Toxicologic Biochemistry, Department of Chemistry, Universidade Federal de Santa Maria, Santa Maria, RS, Brazil, during the period from March 2002 to March 2004.

Eggs of A. gemmatalis were obtained from the Soybean Research National Center (Londrina, PR, Brazil), a unit of the Empresa Brasileira de Pesquisa Agropecuária (EMBRAPA). Larvae were reared on an artificial diet with a 14-h photoperiod at $25 \pm 2{ }^{\circ} \mathrm{C}$ and $50 \pm 10 \%$ relative humidity, as proposed by Hoffmann-Campo et al. (19).

\section{Sample preparation}

Actively feeding last instar larvae were chilled and their midguts were dissected free over ice. After homogenization in cold 0.15 $\mathrm{M} \mathrm{NaCl}(1: 10, \mathrm{w} / \mathrm{v})$, the material was centrifuged at $14,000 \mathrm{~g}$ for $10 \mathrm{~min}$ at $4^{\circ} \mathrm{C}$. The resulting supernatants were pooled, divided into aliquots and frozen at $-20^{\circ} \mathrm{C}$ until required. To obtain gut wall and lumen content, after dissection, midguts were split lengthwise and the walls were washed with cold $0.15 \mathrm{M} \mathrm{NaCl}$; the lumen content and gut wall were homogenized separately $(1: 10, \mathrm{w} /$ v) and then centrifuged as described for total midgut. The samples were stored at $-20^{\circ} \mathrm{C}$, since no alteration of both total proteolytic activity and trypsin-like activity was verified by freezing. A pool of different larval midguts was used for each enzymatic assay.

\section{pH estimation}

The $\mathrm{pH}$ of gut content was estimated using narrow range $\mathrm{pH}$ indicator paper (Merck, Darmstadt, Germany). Immediately after dissection, midguts were split lengthwise and the papers introduced in the middle region. Measurements were obtained from four midguts, and each determination was carried out in triplicate. The $\mathrm{pH}$ paper was compared to the values obtained using standard solutions of known $\mathrm{pH}$ (20).

\section{Enzymatic assays}

Total proteolytic activity was determined by the method of Marchetti et al. (21), with some modifications. Typically, the sample (15 $\mu \mathrm{L}$ containing $10-20 \mu$ g protein) and 0.1 M Tris (21-24) buffer, pH $10.0(360 \mu \mathrm{L})$, were pre-incubated for $5 \mathrm{~min}$ at $30^{\circ} \mathrm{C}$ before the addition of $20 \mu \mathrm{L} 2 \%$ azocasein $(w / v$, in glass-distilled water). After $20 \mathrm{~min}$ of incubation, the reaction was stopped using 400 $\mu \mathrm{L} 10 \%$ trichloroacetic acid (w/v). Tubes were kept on ice for $10 \mathrm{~min}$ and then centrifuged at 5,000 $\mathrm{g}$ for $5 \mathrm{~min} ; 500-\mu \mathrm{L}$ aliquots of the supernatant were withdrawn and mixed in a cuvette with $500 \mu \mathrm{L} 1 \mathrm{M} \mathrm{NaOH}$ and absorbance at $420 \mathrm{~nm}$ was determined. Blanks (test tubes without samples) were run in all cases. The basal activity obtained in the absence of inhibitor or activator at $30^{\circ} \mathrm{C}$ and $\mathrm{pH} 10.0$ was $1.14 \pm 0.15$ variation in absorbance at $420 \mathrm{~nm}(\Delta \mathrm{Abs}) \mathrm{min}^{-1} \mathrm{mg}$ protein $^{-1}$.

Trypsin-like activity was assayed using the chromogenic substrate BApNA (25). Briefly, 0.1 M Tris buffer, pH 10.0 (1.35 $\mathrm{mL})$, and the sample (10 $\mu \mathrm{L}$ containing 5-15 $\mu \mathrm{g}$ protein) were pre-incubated for $5 \mathrm{~min}$ at $30^{\circ} \mathrm{C}$ before the addition of $0.2 \mathrm{~mL} 7.8 \mathrm{mM}$ BApNA (in 13\% dimethyl sulfoxide; $1 \mathrm{mM}$ final concentration) to start the reaction. After $15 \mathrm{~min}$ of incubation, the reaction was stopped with $0.75 \mathrm{~mL} 30 \%$ acetic acid and absorbance was measured at $410 \mathrm{~nm}(\varepsilon=$ $8800 \mathrm{M}^{-1} \mathrm{~cm}^{-1}$ ). Assays were carried out in triplicate and appropriate blanks were run in all cases. The basal specific activity determined in the absence of inhibitor or activator at $30^{\circ} \mathrm{C}$ and $\mathrm{pH} 10.0$ at $410 \mathrm{~nm}$ was $0.217 \pm$ $0.02 \mathrm{mmol}$ p-nitroaniline formed $\mathrm{min}^{-1} \mathrm{mg}$ protein $^{-1}$.

Chymotrypsin-like activity was determined using BTpNA according to the method of Christeller et al. (26). Assays containing 1 mM BTpNA and $1.35 \mathrm{~mL} 0.1 \mathrm{M}$ Tris buffer, pH 10.0 (21) at $410 \mathrm{~nm}$, were carried out as previously described for trypsin-like activity. 


\section{Effect of pH on enzymatic activities}

The effect of $\mathrm{pH}$ on azocasein hydrolysis was evaluated at $\mathrm{pH} 7.0,8.0,9.0,9.5,10.0$, 10.5 , and 11.0 for $0.1 \mathrm{M}$ Tris buffer and at $\mathrm{pH}$ $8.0,9.0,9.5,10.0,10.5$, and 11.0 for $0.1 \mathrm{M}$ glycine buffer. BApNA hydrolysis was evaluated at $\mathrm{pH}$ 8.0, 8.5, 9.0, 9.5, 10.0, 10.5, and 11.0 for both buffers. Buffers were always prepared at the concentration of $0.1 \mathrm{M}$ $(21,23,24)$ and the $\mathrm{pH}$ was corrected by the addition of $1 \mathrm{M} \mathrm{HCl}$ or $1 \mathrm{M} \mathrm{NaOH}$ to reach the $\mathrm{pH}$ values desired for both Tris and glycine. Activities were assayed as described above.

\section{Effect of temperature}

Briefly, 0.1 M Tris buffer and samples were pre-incubated for $5 \mathrm{~min}$ at given temperatures before the addition of the substrate to start the reaction. Assays were carried out as previously detailed. To assess the stability of the enzyme, the buffer and the sample were pre-incubated at given temperatures for 5 or $30 \mathrm{~min}$ (21). Test tubes were then transferred to a water bath at $30^{\circ} \mathrm{C}$. After $2 \mathrm{~min}$, time enough to reach thermoequilibration, the activity was assayed as previously described.

\section{Inhibition studies}

In order to identify the major proteinases present in the midgut of A. gemmatalis, in-

Table 1. Effect of inhibitors and activators on azocasein and BApNA hydrolysis.

\begin{tabular}{lccc} 
Inhibitor/activator & Concentration $(\mathrm{mM})$ & Azocasein (\% control) & BApNA (\% control) \\
\hline EDTA & 10 & 93 & 98 \\
lodoacetic acid & 1 & 96 & 98 \\
L-cysteine & 1 & 72 & 96 \\
2-Mercaptoethanol & 1 & 94 & 100 \\
Ca $^{2+}$ & 10 & 120 & 130 \\
Mg $^{2+}$ & 10 & 136 & 141 \\
\hline
\end{tabular}

Data are reported as means of three or four independent determinations. Standard errors were less than $10 \%$ of the means. Assays were carried out in $0.1 \mathrm{M}$ Tris, $\mathrm{pH} 7.0$, at $30^{\circ} \mathrm{C}$ using $0.1 \%$ azocasein or $1 \mathrm{mM} \mathrm{BApNA}$ as substrates. $\mathrm{Ca}^{2+}$ and $\mathrm{Mg}^{2+}$ assays were carried out in $0.1 \mathrm{M}$ Tris, $\mathrm{pH}$ 10.0. BApNA = N-benzoyl-L-arginine-p-nitroanilide; EDTA = ethylenediaminetetraacetic acid. hibitors and activators of different mechanistic classes were tested. In all cases, samples (15 $\mu \mathrm{L}$ containing $10-20 \mu$ g protein), $0.1 \mathrm{M}$ Tris buffer $(360 \mu \mathrm{L})$ and inhibitor/activator were pre-incubated together for $10 \mathrm{~min}$ (20 min for PMSF) before the addition of substrate to start the reaction.

To investigate the effects of PMSF on proteinase activities the assays were carried out at $30^{\circ} \mathrm{C}$ in $0.1 \mathrm{M}$ Tris, $\mathrm{pH} 7.0$, because this compound precipitates in alkaline medium $(27,28)$. The inhibitor was tested at concentrations ranging from 0 to $0.5 \mathrm{mM}$ for total proteolytic activity and at concentrations ranging from 0 to $2.5 \mathrm{mM}$ for trypsinlike activity. The effects of BZD on both activities were tested using inhibitor concentrations ranging from 0 to $0.5 \mathrm{mM}$ for total proteolytic activity and from 0 to 0.04 $\mathrm{mM}$ for trypsin-like activity, in $0.1 \mathrm{M}$ Tris, $\mathrm{pH} 10.0$, at $30^{\circ} \mathrm{C}$. $\mathrm{IC}_{50}$ values for both inhibitors were calculated by the method of Dixon and Webb (29).

The effects of EDTA, $\mathrm{Ca}^{2+}$ and $\mathrm{Mg}^{2+}(10$ $\mathrm{mM}$ ) and iodoacetic acid, L-cysteine and 2mercaptoethanol $(1 \mathrm{mM})$ were also investigated at appropriate $\mathrm{pH}$ as detailed in Table 1 and preincubated as described earlier. Data are reported as percent relative activity compared to the respective controls (samples without inhibitors/activators).

\section{Protein estimations}

Protein measurements in midgut extracts were done according to the dye-binding method of Bradford (30) using bovine serum albumin fraction $\mathrm{V}$ as standard.

\section{Results}

\section{Proteinase activities}

The $\mathrm{pH}$ of the midgut content of A. gemmatalis larvae ranged from 9.5 to 10.0. Using BApNA as substrate, $82 \%$ of trypsinlike activity was observed in midgut lumen 
content and $18 \%$ in the midgut walls (Table 2). These results are consistent with the view that trypsin is a soluble enzyme secreted by midgut cells into the lumen during digestion (31).

Total proteolytic activity of midgut extracts in terms of azocasein hydrolysis increased with $\mathrm{pH}$ increase from 7.0 to 11.0 , with a maximum rate at $\mathrm{pH} 10.5$ for both Tris and glycine buffers. Only $16 \%$ of the maximum activity was observed in Tris, $\mathrm{pH}$ 7.0, and glycine, $\mathrm{pH}$ 8.0, buffers. Trypsin-like activity showed a maximum rate of BApNA hydrolysis at $\mathrm{pH} 10.0$ when Tris buffer was used. However, the optimum $\mathrm{pH}$ shifted slightly to $\mathrm{pH} 10.5$ with glycine buffer (Figure 1).

Attempts to detect chymotrypsin-like activity using BTpNA as substrate failed. It is known that some insect chymotrypsins only cleave synthetic substrates with more than one amino acid residue $(13,27,32)$.

\section{Effect of temperature}

Proteolytic activity on the basis of BApNA hydrolysis was temperature dependent and maximum activity was obtained at $50^{\circ} \mathrm{C}$ (Figure 2). The thermal stability of trypsin-like activity in the midgut samples pre-incubated for $5 \mathrm{~min}$ remained unchanged at temperatures up to $40^{\circ} \mathrm{C}$. However, preincubation for $30 \mathrm{~min}$ at temperatures of $40^{\circ} \mathrm{C}$ or more sharply reduced the proteolytic activity, which was almost abolished at $60^{\circ} \mathrm{C}$ (Figure 3).

\section{Inhibition studies}

PMSF inhibited the proteolytic activities with an $\mathrm{IC}_{50}$ of $0.39 \mathrm{mM}$ for azocasein hydrolysis and of $1.35 \mathrm{mM}$ for BApNA hydrolysis (Figure 4). BZD also inhibited the hydrolysis of both substrates (Figure 5), with an $\mathrm{IC}_{50}$ of 0.69 and $0.076 \mathrm{mM}$ for azocasein and BApNA, respectively.

The cysteine-proteinase inhibitor iodoacetic acid had no significant effect on

total proteolytic activity (only $4 \%$ inhibition; Table 1). The absence of cysteine-proteinases is confirmed by the fact that 2mercaptoethanol and L-cysteine did not enhance azocasein hydrolysis. The inhibition of proteolytic activity by L-cysteine may be a consequence of interactions with the substrate, since higher concentrations of L-cysteine precipitated azocasein. EDTA, a metalchelating agent, did not inhibit azocasein hydrolysis to a great extent, suggesting that metalloproteinase is not a major constituent of midgut extracts. Trypsin-like activity was

Table 2. Compartmentalization of trypsin-like enzymes in midgut of Anticarsia gemmatalis larvae.

\begin{tabular}{lcc}
\hline Site & $\begin{array}{c}\text { Specific activity } \\
\left(\mathrm{mmol} \text { p-nitroaniline } \mathrm{min}^{-1} \mathrm{mg}^{-1}\right)\end{array}$ & $\begin{array}{c}\text { Relative activity } \\
(\%)\end{array}$ \\
\hline Gut walls & $0.065 \pm 0.002$ & 18 \\
Gut contents & $0.300 \pm 0.006$ & 82 \\
\hline
\end{tabular}

Data are reported as means \pm SEM of three independent determinations.
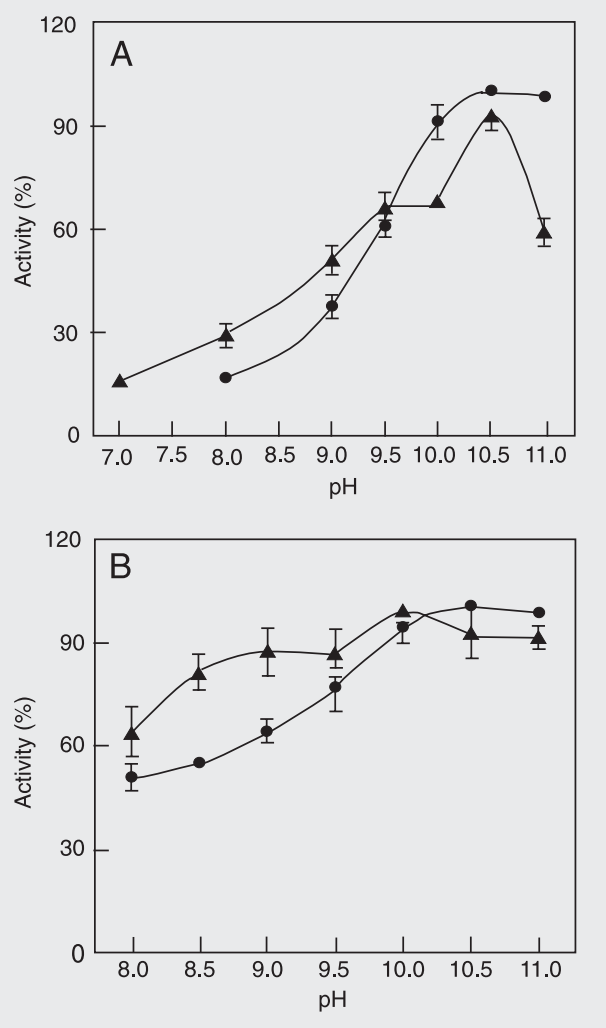

Figure 1. $\mathrm{pH}$ curves of proteinase activities from the larval midgut of Anticarsia gemmatalis. $A$, Effect of $\mathrm{pH}$ on the hydrolysis of $0.1 \%$ azocasein. $B$, Effect of $\mathrm{pH}$ on the hydrolysis of $1 \mathrm{mM} \mathrm{N}$-benzoyl-L-arginine-pnitroanilide. Buffers used were $0.1 \mathrm{M}$ Tris (triangles) and $0.1 \mathrm{M}$ glycine (circles). Data are reported as means \pm SEM of four independent determinations. 
not affected by any of the thiol reagents tested, i.e., iodoacetic acid, 2-mercaptoethanol and L-cysteine. EDTA also had no effect. $\mathrm{Ca}^{2+}$ and $\mathrm{Mg}^{2+}$ enhanced azocasein and BApNA hydrolysis around 30\% (Table 1).

Figure 2. Effect of temperature on trypsin-like activity from the larval midgut of Anticarsia gemmatalis. N-benzoyl-L-arginine-pnitroanilide $(1 \mathrm{mM})$ hydrolysis was measured at given temperatures in $0.1 \mathrm{M}$ Tris, $\mathrm{pH} 10.0$, for $15 \mathrm{~min}$. Data are reported as means \pm SEM of three independent determinations.

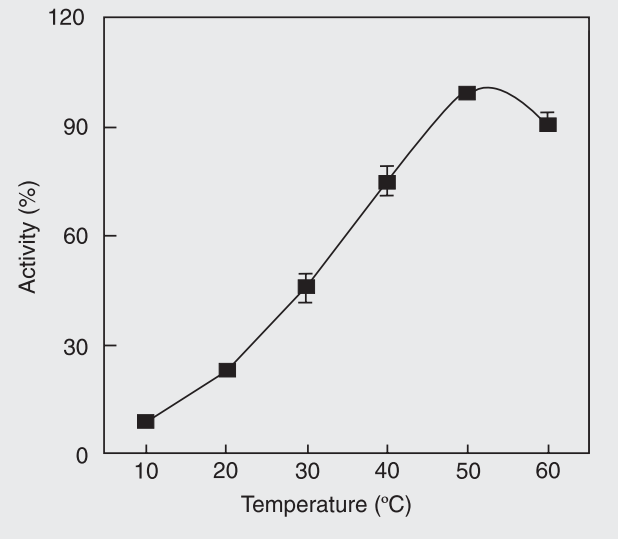

Figure 3. Thermal stability of trypsin-like enzymes from the larval midgut of Anticarsia gemmatalis. Samples were pre-incubated at given temperatures in $0.1 \mathrm{M}$ Tris, $\mathrm{pH} 10.0$, for $5 \mathrm{~min}$ (open circles) and $30 \mathrm{~min}$ (filled circles). After 2 min of thermoequilibration at $30^{\circ} \mathrm{C}, \mathrm{N}$-benzoyl-L-arginine-p-nitroanilide (1 $\mathrm{mM}$ ) was added to start the reaction (15 min). Data are reported as means \pm SEM of three independent determinations.

Figure 4. Inhibition of trypsin-like and total proteolytic activities from the larval midgut of Anticarsia gemmatalis by phenylmethylsulfonyl fluoride (PMSF). Assays were carried out in 0.1

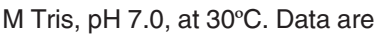
reported as means \pm SEM of three independent determinations. BApNA $=\mathrm{N}$-benzoyl-L-arginine-p-nitroanilide.
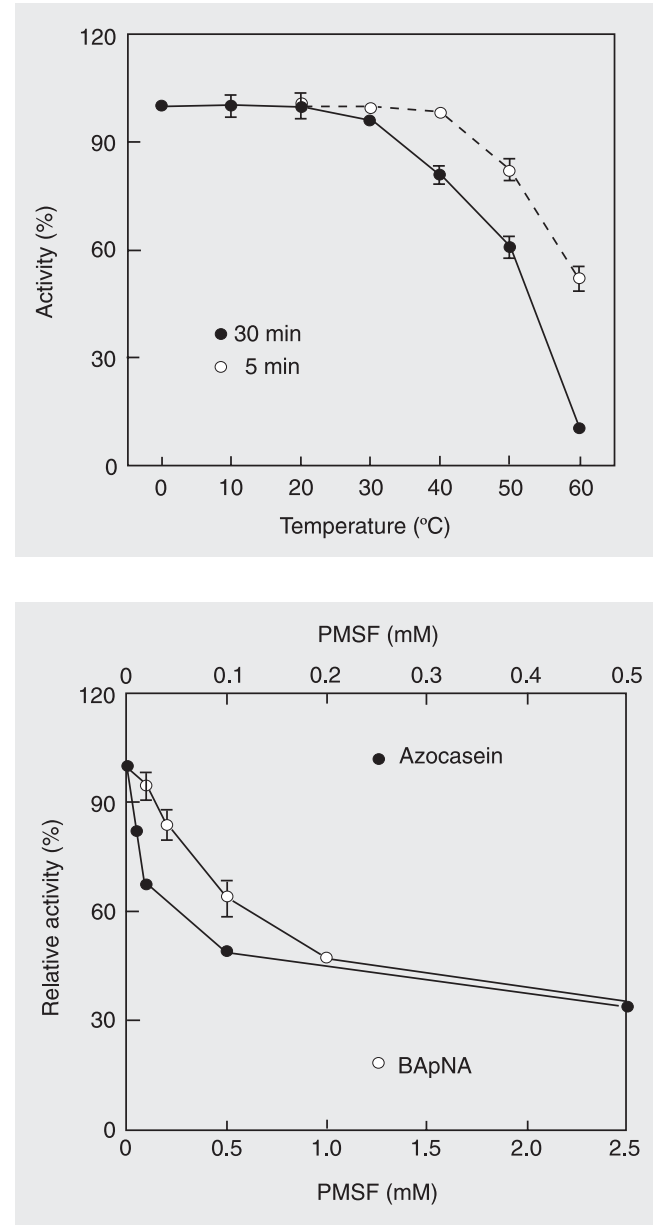

\section{Discussion}

The alkaline $\mathrm{pH}$ (9.5-10.0) of the midgut of A. gemmatalis is similar to that reported in other investigations of Lepidoptera larvae, whose midgut content had a $\mathrm{pH}$ of 8.0 to $12.0(24,27,31,33)$. Teo et al. (34) have reported a $\mathrm{pH}$ of 7.6 for the midgut content of A. gemmatalis larvae. This discrepancy may be due to the different methods used by these investigators to estimate midgut $\mathrm{pH}$ that disrupted the regulatory process necessary to maintain it (35). The hydrolysis of the substrates, BApNA and azocasein, is influenced by the buffers used in $\mathrm{pH}$ studies. The effects of buffer systems on enzymatic assays have been reported previously for insect digestive enzymes $(27,36)$.

The $\mathrm{pH}$ value of 10.5 for maximal proteolytic activity using both buffers corresponded to the second peak of $\mathrm{pH} 10.0$ reported for this insect by Teo et al. (34), who also found a peak of activity at $\mathrm{pH}$ 7.6. The alkaline optimum $\mathrm{pH}$ for azocasein hydrolysis strongly suggests the presence of serineproteinases in midgut extracts, confirming the occurrence of protein digestion in this insect (13).

The trypsin-like activity was strongly temperature dependent and was similar to that reported for other Lepidoptera larvae (21, 27,37). The effect of temperature on the metabolism of these insects and consequently on their life cycle is well known (38). Leppla et al. (39) have reported that, at $21.1^{\circ} \mathrm{C}$, larvae require almost twice the time to complete their development to pupae when compared to larvae reared at $32.2^{\circ} \mathrm{C}$ under laboratory conditions.

The principal catalytic activities responsible for proteolysis were determined using inhibitors and activators of different mechanistic classes. The presence of serine-proteinases was confirmed by the fact that PMSF (Figure 4), an inhibitor considered to be diagnostic for this class of proteinase, caused $50 \%$ inhibition of azocasein hydrolysis at 
$0.39 \mathrm{mM}$ and $50 \%$ inhibition of BApNA hydrolysis at $1.35 \mathrm{mM}$. This small difference in $\mathrm{IC}_{50}$ between the two activities suggests an important contribution of trypsinlike activity to the total proteolytic activity detected on azocasein hydrolysis.

To confirm this participation we also tested the effect of BZD, an inhibitor considered to be characteristic for trypsin, on total proteolytic and trypsin-like activities (Figure 5). The results demonstrated a pronounced difference in the sensitivities of enzymatic activities to the inhibitor, since an inhibitor concentration about 10 times higher was necessary to inhibit azocasein hydrolysis $\left(\mathrm{IC}_{50}=0.69 \mathrm{mM}\right)$ compared to BApNA hydrolysis $\left(\mathrm{IC}_{50}=0.076 \mathrm{mM}\right)$. These results agree with those reported by Oliveira et al. (22) who detected a higher sensitivity of the proteolytic activity of the partially purified fraction to BZD than to PMSF. The absence of important effects of other compounds tested rules out a strong participation of other proteinase activities. As a whole, these results demonstrate the presence of trypsinlike enzymes in midgut extracts due to their high sensitivity to the inhibitor, high rate of BApNA hydrolysis, and occurrence mainly in midgut content (Table 2). In addition, these results agree with data reported by other investigators who detected the presence of trypsin-like activity in several species of Lepidoptera $(15,16)$, as well as in the A. gemmatalis species (22).

In contrast with other reports, which showed that trypsin-like enzymes from insect sources do not need divalent cations to reach their maximum activities $(25,35)$, we observed that calcium and magnesium activated BApNA and azocasein hydrolysis. Similar results were obtained by Oliveira et

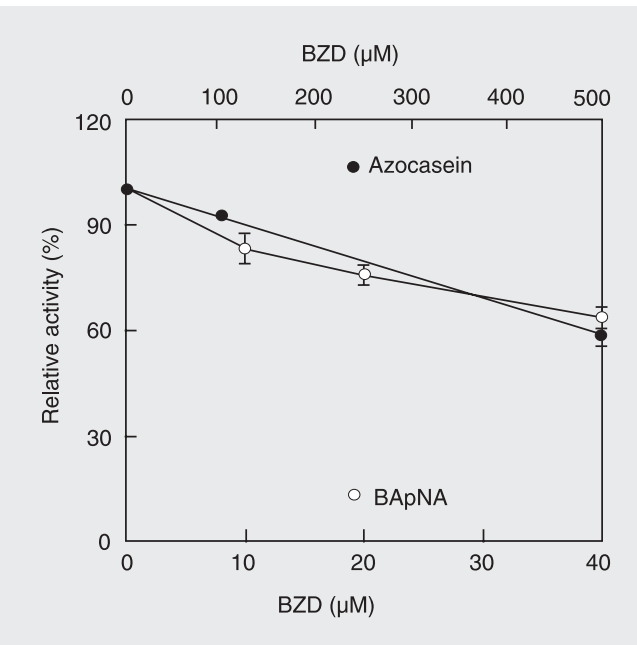

Figure 5. Inhibition of trypsin-like and total proteolytic activities from the larval midgut of Anticarsia gemmatalis by benzamidine (BZD). Assays were carried out in $0.1 \mathrm{M}$ Tris, $\mathrm{pH} 10.0$, at $30^{\circ} \mathrm{C}$. Data are reported as means \pm SEM of three independent determinations. BApNA $=\mathrm{N}$-benzoyl-L-arginine-p-nitroanilide.

al. (22) using $\mathrm{Ca}^{2+}$, and by Houseman et al. (40) and Bernardi et al. (37), who reported that $\mathrm{Mg}^{2+}$ was the best activator of trypsinlike activity when crude midgut extracts were assayed. Interestingly, the addition of EDTA to the reaction medium prevented the activation effects (data not shown).

The present study was carried out using crude extracts of midgut obtained after homogenate centrifugation and after partial characterization. Thus, it was possible to demonstrate that we were working with a mixture of proteinases with features similar to those of trypsin. The present study shows the predominance of trypsin-like proteases in the midgut of A. gemmatalis, which could be targeted with specific inhibitors to achieve insect control.

\section{Acknowledgments}

The authors gratefully acknowledge EMBRAPA - Soja (Londrina, PR, Brazil), especially Dr. F. Moscardi, for supplying the eggs of Anticarsia gemmatalis. 


\section{References}

1. Kogan M \& Turnipseed SG (1987). Ecology and management of soybean arthropods. Annual Review of Entomology, 32: 507-538.

2. Turnipseed SG \& Kogan M (1976). Soybean entomology. Annual Review of Entomology, 21: 247-282.

3. Fuxa JR \& Richter AR (1999). Classical biological control in an ephemeral crop habitat with Anticarsia gemmatalis nucleopolyhedrovirus. Biocontrol, 44: 405-421.

4. Gazzoni DL (1994). Manejo de Pragas da Soja: Uma Abordagem Histórica. EMBRAPA - Serviço de Produção de Informação, Brasília, DF, Brazil.

5. Ribeiro BM \& Crook NE (1998). Construction of occluded recombinant baculoviruses containing the full-length $c r y 1 A b$ and $c r y 1 A c$ genes from Bacillus thuringiensis. Brazilian Journal of Medical and Biological Research, 31: 763-769.

6. Gatehouse AMR \& Gatehouse JA (1998). Identifying proteins with insecticidal activity: use of encoding genes to produce insect-resistant transgenic crops. Pesticide Science, 52: 165-175.

7. Ryan CA (1990). Proteinase inhibitors in plants: genes improving defenses against insects and pathogens. Annual Review of Phytopathology, 28: 425-449.

8. Broadway RM, Duffey SS, Pearce G et al. (1986). Plant proteinase inhibitors: a defense against herbivorous insects. Entomologia Experimentalis et Applicata, 41: 33-38.

9. Hilder VA, Gatehouse AMR, Sheerman SE et al. (1987). A novel mechanism for insect resistance engineered into tobacco. Nature, 330: 160-163.

10. Johnston KA, Gatehouse JA \& Anstee JH (1993). Effects of soybean protease inhibitors on the growth and development of larval Helicoverpa armigera. Journal of Insect Physiology, 39: 657-664.

11. Heath RL, McDonald G, Christeller JT et al. (1997). Proteinase inhibitors from Nicotiana alata enhance plant resistance to insect pests. Journal of Insect Physiology, 43: 833-842.

12. Gatehouse AMR, Davison GM, Newell CA et al. (1997). Transgenic potato plants with enhanced resistance to the tomato moth, Lacanobia oleracea: growth room trials. Molecular Breeding, 3: 4963.

13. Gatehouse AMR, Norton E, Davison GM et al. (1999). Digestive proteolytic activity in larvae of tomato moth, Lacanobia oleracea; effects of plant protease inhibitors in vitro and in vivo. Journal of Insect Physiology, 45: 545-558.

14. Broadway RM \& Duffey SS (1986). Plant proteinase inhibitors: mechanism of action and effect on the growth and digestive physiology of larval Heliothis zea and Spodoptera exiqua. Journal of Insect Physiology, 32: 827-833.

15. Terra WR \& Ferreira C (1994). Insect digestive enzymes: properties, compartmentalization and function. Comparative Biochemistry and Physiology, 109B: 1-62.

16. Applebaum SW (1985). Biochemistry of digestion. In: Kerkut GA \& Gilbert LI (Editors), Comparative Insect Physiology, Biochemistry and Pharmacology. Vol. IV. Pergamon, Toronto, Canada.

17. Milne R \& Kaplan H (1993). Purification and characterization of a trypsin-like digestive enzyme from spruce budworm (Choristoneura fumiferana) responsible for the activation of $\delta$-endotoxin from BacilIus thuringiensis. Insect Biochemistry and Molecular Biology, 6: 665-673.

18. Bobrowski VL, Pasquali G, Bodanese-Zanettini MH et al. (2002). Characterization of two Bacillus thuringiensis isolates from South Brazil and their toxicity against Anticarcia gemmatalis (Lepidoptera:
Noctuidae). Biological Control, 25: 129-135.

19. Hoffmann-Campo CB, Oliveira EB \& Moscardi F (1985). Criação Massal da Lagarta da Soja (Anticarsia gemmatalis). EMBRAPA, Serviço de Produção de Informação, Brasília, DF, Brazil.

20. Walker AJ, Ford L, Majerus MEN et al. (1998). Characterisation of the midgut digestive proteinase activity of the two-spot ladybird (Adalia bipunctata L.) and its sensitivity to proteinase inhibitors. Insect Biochemistry and Molecular Biology, 28: 173-180.

21. Marchetti S, Chiabà C, Chiesa F et al. (1998). Isolation and partial characterization of two trypsins from the larval midgut of Spodoptera littoralis (Boisduval). Insect Biochemistry and Molecular Biology, 28: 449-458.

22. Oliveira MGA, De Simone SG, Xavier LP et al. (2005). Partial purification and characterization of digestive trypsin-like proteases from the velvet bean caterpillar, A. gemmatalis. Comparative Biochemistry and Physiology. Part B, Biochemistry and Molecular Biology, 140: 369-380.

23. Christeller JT, Laing WA, Markwick NP et al. (1992). Midgut protease activities in 12 phytophagous lepidopteran larvae: dietary and protease inhibitor interactions. Insect Biochemistry and Molecular Biology, 22: 735-746.

24. Pritchett DW, Young SY \& Geren CR (1981). Proteolytic activity in the digestive fluid in larvae of Trichoplusia ni. Insect Biochemistry, 11: 523-526.

25. Erlanger BF, Kokowsky N \& Cohen W (1961). The preparation and properties of two new chromogenic substrates of trypsin. Archives of Biochemistry and Biophysics, 95: 271-278.

26. Christeller JT, Shaw BD, Gardiner SE et al. (1989). Partial purification and characterization of the major midgut proteases of grass grub larvae (Costelytra zealandica, Coleoptera: Scarabaeidae). Insect Biochemistry, 19: 221-231.

27. Lee MJ \& Anstee JH (1995). Endoproteases from the midgut of larval Spodoptera littoralis include a chymotrypsin-like enzyme with an extended binding site. Insect Biochemistry and Molecular Biology, 25: 49-61.

28. Brown DP, Wilkinson HS \& Gatehouse JA (1997). Differentially regulated inhibitor-sensitive and insensitive protease genes from the phytophagous insect pest, Helicoverpa armigera, are members of complex multigene families. Insect Biochemistry and Molecular Biology, 27: 625-638.

29. Dixon M \& Webb EC (1964). Enzymes. 2nd edn. Longmans, Green and Co., Ltd., London, UK.

30. Bradford MM (1976). A rapid and sensitive method for the quantitation of microgram quantities of protein utilizing the principle of protein-dye binding. Analytical Biochemistry, 72: 255-260.

31. Terra WR (1988). Physiology and biochemistry of insect digestion: an evolutionary perspective. Brazilian Journal of Medical and Biological Research, 21: 675-734.

32. Johnston KA, Lee MJ, Brough C et al. (1995). Protease activities in the larval midgut of Heliothis virescens: evidence for trypsin and chymotrypsin-like enzymes. Insect Biochemistry and Molecular Biology, 25: 375-383.

33. Purcell JP, Greenplate JT \& Sammons RD (1992). Examination of midgut luminal proteinase activities in six economically important insects. Insect Biochemistry and Molecular Biology, 22: 41-47.

34. Teo LH, Hammond AM, Woodring JP et al. (1990). Digestive enzymes of the velvetbean caterpillar (Lepidoptera: Noctuidae). Annals of the Entomological Society of America, 88: 820-826. 
35. Harrison JF (2001). Insect acid-base physiology. Annual Review of Entomology, 46: 221-250.

36. Johnston KA, Lee MJ, Gatehouse JA et al. (1991). The partial purification and characterization of serine protease activity in midgut of larval Helicoverpa armigera. Insect Biochemistry, 21: 389-397.

37. Bernardi B, Tedeschi G, Ronchi S et al. (1996). Isolation and some molecular properties of a trypsin-like enzyme from larvae of European corn borer Ostrinia nubilalis Hübner (Lepidoptera: Pyralidae). Insect Biochemistry and Molecular Biology, 26: 883-889.

38. Gazzoni DL, Pedroso Junior M, Garagorry F et al. (1998). Math- ematical simulation model of the velvetbean caterpillar. Pesquisa Agropecuária Brasileira, 33: 385-396.

39. Leppla NC, Ashley TR, Guy RH et al. (1977). Laboratory life history of the velvetbean caterpillar. Annals of the Entomological Society of America, 70: 217-220.

40. Houseman JG, Philogène BJR \& Downe AER (1989). Partial characterization of proteinase activity in the larval midgut of the European corn borer, Ostrinia nubilalis Hübner (Lepidoptera: Pyralidae). Canadian Journal of Zoology, 67: 864-867. 